\title{
Studies on the Development of an ELISA Kit for Microbiological Monitoring
}

\section{Improvement of the Prototype ELISA Kit with Special \\ References to Mouse Hepatitis Virus Antigen}

\author{
Naoko KAGIYAMA, Akira TAKAKURA, Eiji TERADA*, \\ Yoshinori SAKURAI**, and Hirokazu SUZUKI**
}

\begin{abstract}
Department of Laboratory Animal Medicine, Central Institute for Experimental Animals, 1430 Nogawa, Miyamae-ku, Kawasaki-shi 213, Japan, * Department of Laboratory Animal Science, School of Hygienic Sciences, Kitasato University, Kitasato, Sagamihara-shi 228, and ${ }^{* *}$ Wakamoto Pharmaceutical Co. Ltd., 378 Kanade, Ohi-machi, Ashigarakamigun, Kanagawa 258
\end{abstract}

(Received 5 July 1989/Accepted 22 September 1989)

\begin{abstract}
Improvement of the mouse hepatitis virus (MHV) antigen in a prototype ELISA kit was performed. Equivalent divalent antigens of $\mathrm{MHV} \mathrm{Nu}-67$ and $\mathrm{S}$ strains with a protein concentration of $10 \mu \mathrm{g} / \mathrm{ml}$ showed the best sensitivity and specificity for the detection of MHV and sialodacryoadenitis/Parker's rat coronavirus antibodies in mice and rats, respectively. An increase in the reliability of macroscopic evaluation of both antibody tests is expected by using the newly manufacturedkit with the improved antigen.
\end{abstract}

We reported on the trial manufacture of ELISA kits with Sendai virus and mouse hepatitis virus (MHV) antigens [4]. Their reliability evaluations were performed by field tests. For the prototype kit, $\mathrm{MHV} \mathrm{Nu}-67$ ( $5 \mu \mathrm{g} / \mathrm{ml}$ of protein concentration) was selected for detection of MHV antibody in mice and sialodacryoadenitis virus (SDAV)/Parker's rat coronavirus (PCV) antibodies in rats.

Some discrepancies in the results (instrument evaluation versus macroscopic evaluation) in MHV and SDAV/PCV antibody tests were seen for both the positive and negative regions. Agreement rates of the macroscopic evaluation with instrument evalution were $74.2 \%$ in the positive region and $69.2 \%$ in the negative region for mice and $36.8 \%$ in the positive region and $92.1 \%$ in the negative region for rats in the second field test. The cause of the discrepancies was investigated by analysis of histograms of absorbance values shown in instrument evaluation. No clear peak of absorbance was formed in the positive region and $7-12 \%$ of the serum samples showed absorbances of 0.2-0.4 in the cut-off range.

Thus, the narrowness of the reactivity and insufficient titer of the prototype MHV antigen were suggested in the previous study as the main reasons for those discrepancies. Therefore, an attempt was made to improve the MHV antigen formula.

\section{Materials and Methods}

Antigen preparation : In addition to $\mathrm{Nu}^{-}$ 67 used as the antigen strain in the prototype kit, the S, A 59 and JHM strains of MHV and SDAV 681 strain were used. Each MHV strain was propagated and treated for antigen preparation according to our previous report [3]. SDAV was propagated by inoculation of the virus to LBC cells [2], kindly provided by Dr. Hirano, Iwate University, and treated by the same procedures as described for preparation of the antigen. Protein concentrations of these antigens were adjusted to $5 \mu \mathrm{g} / \mathrm{ml}$. For investigation of the optimum protein concentration, $\mathrm{Nu}-67$ antigens with protein concentra- 
tions of $12.5,10,7.5$ and $5 \mu \mathrm{g} / \mathrm{ml}$ were also prepared.

Serum samples: With the exception of the Nu-67 strain hyperimmune serum of a mouse used for investigation of the antigen concentration, all of the mouse and rat sera, diluted to $1: 40$ with saline, were those collected in the previously reported field tests. Seventy samples each of mouse and rat sera, the majority of which had shown weak reactivity with $\mathrm{Nu}-67$ antigen in the field test, were used for evaluation of the reactivity of the antigen strains (Tables 1, 2 and Fig. 1). Ninety samples each of the sera were used for evaluation of the improved effects of the kit. Among these samples, 45 each originated from breeder colonies proved MHV or SDAV/PCV noncontaminated by routine seromonitoring and pathology (non-contaminated colonies) and the remaining 45 samples were obtained from colonies which showed positive reactions for MHV Nu-67 and/or MHV-2 antigens by the complement fixation test in the past. Some of these colonies had experienced outbreaks of epizootic hepatitis in nude mice or SDA in rats (contaminated colonies).

ELISA : ELISA was performed as reported previously [7]. Absorbance values were measured by spectrophotometry (MTP-12 2-wavelenth microplate photometer ; Corona Electric).

\section{Results}

Ten samples each of mouse sera obtained from colonies $\mathrm{A}$ and $\mathrm{B}$ were examined concerning reactivity with the four MHV antigens. As shown in Table 1, four out of 10 samples from colony $A$ showed higher reaction rates for the A 59 and S strains, followed by three

Table 1. Reactivities of mouse (Facilities A and B) and rat (Facilities

$\mathrm{C}-\mathrm{H}$ ) sera with four mouse hepatitis virus antigens

\begin{tabular}{|c|c|c|c|c|}
\hline \multirow{2}{*}{ Facilities } & \multicolumn{4}{|c|}{ Antigens } \\
\hline & $\mathrm{Nu}-67$ & $\mathrm{JHM}$ & A59 & $\mathrm{S}$ \\
\hline \multirow{2}{*}{ A } & $1 / 10(10)^{*}$ & $3 / 10(30)$ & $4 / 10(40)$ & $4 / 10(40)$ \\
\hline & $0.205^{* *}$ & $0.258-0.524$ & $0.372-0.780$ & $0.242-0.668$ \\
\hline \multirow{2}{*}{ B } & $0 / 10(0)$ & $1 / 10(10)$ & $2 / 10(20)$ & $2 / 10(20)$ \\
\hline & & 0.328 & $0.240-0.472$ & $0.220-0.430$ \\
\hline \multirow{2}{*}{$\mathrm{C}$} & $6 / 10(60)$ & $5 / 10(50)$ & $5 / 10(50)$ & $6 / 10(60)$ \\
\hline & $0.300-1.254$ & $0.566-1.062$ & $0.734-1.072$ & $0.220-1.274$ \\
\hline \multirow{2}{*}{ D } & $3 / 5(60)$ & $3 / 5(60)$ & $3 / 5(60)$ & $3 / 5(60)$ \\
\hline & $0.806-1.316$ & $0.446-0.834$ & $0.566-0.974$ & $0.556-1.130$ \\
\hline \multirow{2}{*}{$\mathrm{E}$} & $6 / 6(100)$ & $5 / 6(83.3)$ & $6 / 6(100)$ & $6 / 6(100)$ \\
\hline & $0.340-0.842$ & $0.250-0.506$ & $0.254-0.608$ & $0.265-0.686$ \\
\hline \multirow{2}{*}{$\mathrm{F}$} & $7 / 10(70)$ & $3 / 10(30)$ & $1 / 10(10)$ & $5 / 10(50)$ \\
\hline & $0.255-0.386$ & $0.225-0.312$ & 0.376 & $0.220-0.382$ \\
\hline \multirow{2}{*}{ G } & $7 / 10(70)$ & $5 / 10(50)$ & $5 / 10(50)$ & $7 / 10(70)$ \\
\hline & $0.260-0.476$ & $0.252-0.374$ & $0.308-0.580$ & $0.256-0.518$ \\
\hline \multirow{2}{*}{$\mathrm{H}$} & $6 / 8(75)$ & $5 / 8(62.5)$ & $2 / 8(25)$ & $6 / 8(75)$ \\
\hline & $0.260-0.476$ & $0.208-0.236$ & $0.225-0.306$ & $0.220-0.424$ \\
\hline
\end{tabular}

${ }^{*}$ No. showing absorbance value of 0.2 or higher/No. tested (\%) ${ }^{* *}$ Range of absorbance values 
Table 2. Reactivities of rat sera (Facilities I-K) with divalent (MHV $\mathrm{Nu}-67+\mathrm{S}$ ) and monovalent $\mathrm{Nu}-67$, S or SDAV 681 antigen

\begin{tabular}{cllll}
\hline \multirow{2}{*}{ Facilities } & \multicolumn{4}{c}{ Antigens } \\
\cline { 2 - 5 } & \multicolumn{1}{c}{ Divalent } & \multicolumn{1}{c}{$\mathrm{Nu} 67$} & \multicolumn{1}{c}{$\mathrm{S}$} & \multicolumn{1}{c}{ SDAV 681 } \\
\hline \multirow{2}{*}{$\mathrm{I}$} & $3 / 5(60)^{*}$ & $3 / 5(60)$ & $3 / 5(60)$ & $3 / 5(60)$ \\
& $0.566^{-0}-0.713^{* *}$ & $0.404-0.658$ & $0.278^{-0}-565$ & $0.406-0.742$ \\
& & & & \\
$\mathrm{~J}$ & $8 / 10(80)$ & $6 / 10(60)$ & $6 / 10(60)$ & $7 / 10(70)$ \\
& $0.292-1.759$ & $0.450-0.753$ & $0.226-0.699$ & $0.511-1.458$ \\
& & & & \\
\multirow{2}{*}{$\mathrm{K}$} & $6 / 6(100)$ & $6 / 6(100)$ & $5 / 6(83.3)$ & $6 / 6(100)$ \\
& $0.480-1.086$ & $0.378-0.842$ & $0.236-0.786$ & $0.485-0.970$ \\
\hline
\end{tabular}

* No. showing absorbance value of 0.2 or higher/No. tested $(\%)$

** Range of absorbance values

for the JHM and one for the $\mathrm{Nu}-67$. Two out of ten samples from colony $B$ reacted with the A 59 and S, one with JHM and none of them reacted with the $\mathrm{Nu}-67$ strain. Reactivity of 49 rat sera from six colonies $(\mathrm{C}-\mathrm{H})$ were investigated for the four MHV antigens. Their highest reaction rates were $60-100 \%$ for $\mathrm{Nu}-67$, followed by $50-100 \%$ for S. Positivity for the A 59 and JHM strains varied in the 10-100\% and $30-83.5 \%$ ranges, respectively.

From these results, equivalent divalent antigens of $\mathrm{Nu}-67$ and $\mathrm{S}$ were prepared, and the reactivity of the antigens with 21 rat sera collected from three colonies (I-K) was investigated in comparison with that of monovalent $\mathrm{Nu}-67, \mathrm{~S}$ or SDAV antigen (Table 2). Higher absorbance values than those obtained by $\mathrm{Nu}^{-}$ 67 or S antigen were demonstrated using the divalent antigens although there were no significant differences in antibody detection rates among these antigens. The divalent antigens showed a high reactivity similar to that of SDAV antigen. Absorbance values of these 21 serum samples obtained by using the divalent antigens correlated well with those obtained by SDAV antigen (correlation coefficient $=0.88$ ).

The reactivity of the divalent antigens was investigated using 50 mouse sera from four colonies ( $\mathrm{L}-\mathrm{O})$. These sera had shown a cut-off absorbance range of $0.2-0.4$ in the previous field tests and macroscopic evaluation of the reaction had been difficult. Twenty-two of the 50 samples (44\%) showed stronger chromogenic reactions with absorbance values of at least

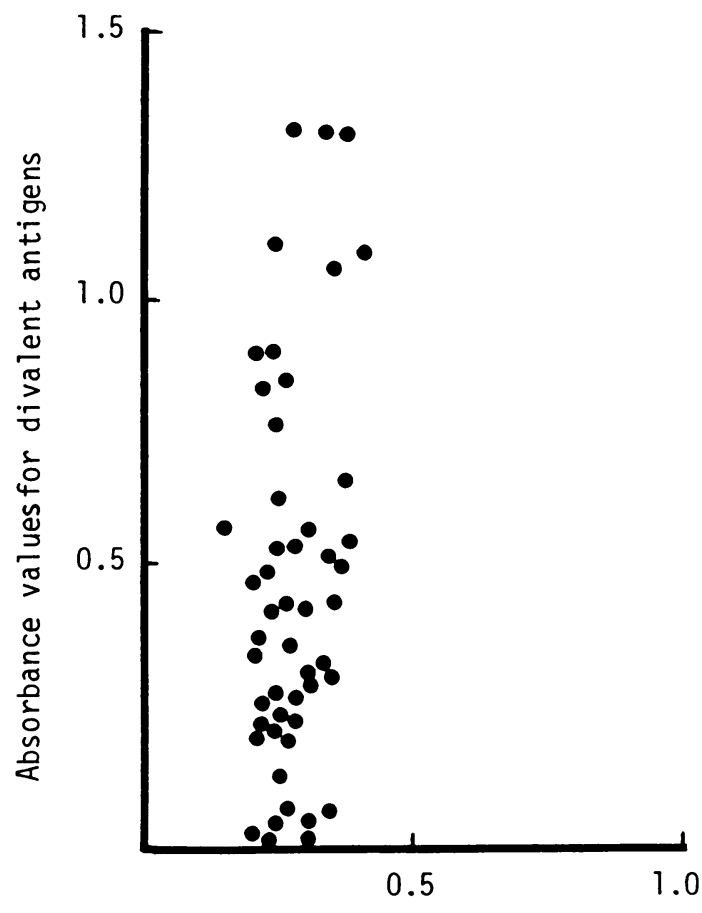

Absorbance values for $\mathrm{Nu}-67$ antigen

Fig. 1. Comparison of absorbance values (492 $\mathrm{nm}$ ) of 50 mouse sera against divalent (MHV $\mathrm{Nu}-67+\mathrm{S}$ ) and monovalent $\mathrm{Nu}-67$ antigens

0.5 for the divalent antigens (Fig. 1).

Protein concentration of the antigen was reevaluated. Fig. 2 shows the reaction curves of $\mathrm{Nu}-67$ antigen at protein concentrations of 


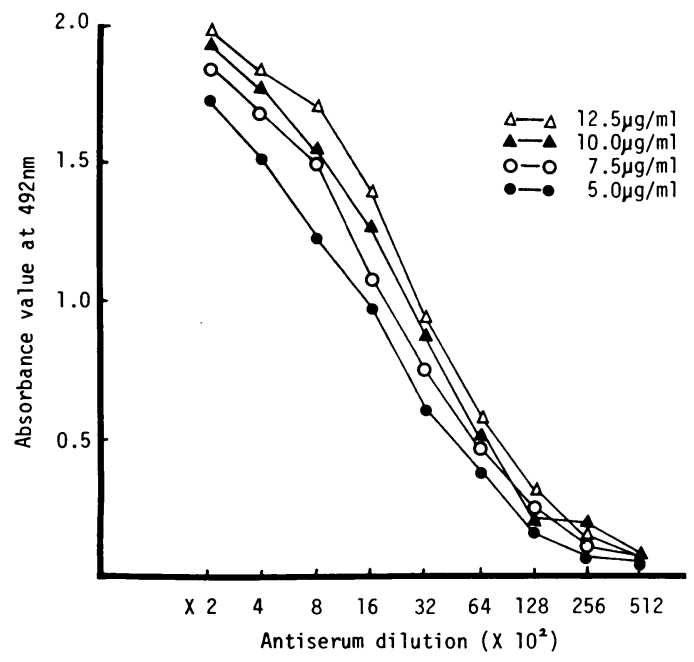

Fig. 2. Reactivity of MHV Nu-67 antigen with various protein concentrations againstmouseantiserum

5-12.5 $\mu \mathrm{g} / \mathrm{ml}$ with a homologous mouse hyperimmune serum. Ten $\mu \mathrm{g} / \mathrm{ml}$ seemed the minimum protein concentration for obtaining a clearreaction because of its sigmoid reaction curve.

$\mathrm{Nu}-67$ and $\mathrm{S}$ divalent antigen plates with a protein concentration of $10 \mu \mathrm{g} / \mathrm{ml}$ were newly prepared and the improvement effect, compared with Nu-67 antigen, was evaluated from the reactivity with 90 mouse and 90 rat sera collected from MHV or SDAV/PCV non-contaminated (45 each) and contaminated (45 each) colonies. The reaction of the divalent antigens with mouse sera showed a clear distinction between the non-contaminated and contaminated groups with absorbance values of -0.1-0.1 from the former and $0.3-2.1$ from the latter (Fig. 3-a). On the other hand, such a distinction between the two groups did not appear using Nu-67 monovalent antigen with a protein concentration of $5 \mu \mathrm{g} / \mathrm{ml}$ (Fig. 3-b). All 45 mouse sera obtained from non-contaminated colonies showed absorbance values in the range -0.1 to 0.1 , whereas those obtained from contaminated colonies were widely distributed as follows : 14 in the range 0.1 to $0.3,11$ in the range 0.3 to 0.5 and 20 in the range 0.5 to 2.1 .

The reactivity of the two types of antigens with rat sera is shown in Figures 4-a and 4-b. In using the divalent antigens (Fig. 4-a), the

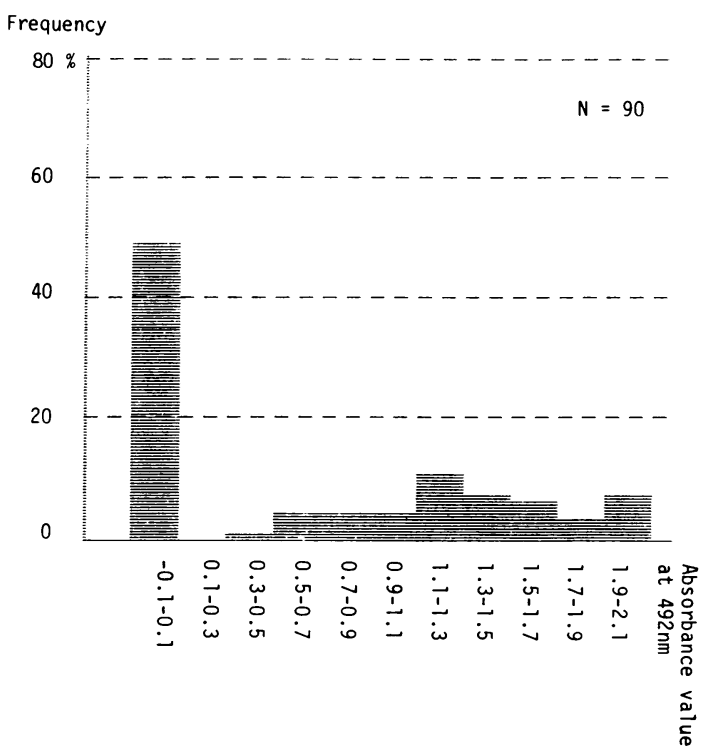

Fig. 3-a. Distribution of absorbance values in ELISA on mouse hepatitis virus antibody in mice using divalent (MHV Nu-67+S) antigens

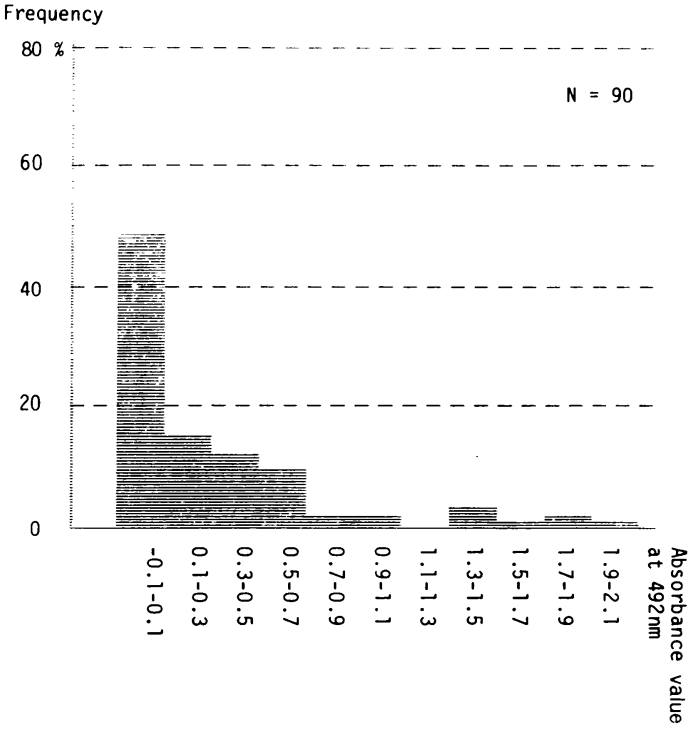

Fig. 3-b. Distribution of absorbance values in ELISA on mouse hepatitis virus antibody in

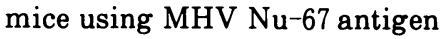

absorbance values of 45 sera collected from non-contaminated colonies ranged from -0.1 to 0.1 , except for one sample (range $0.1-0.3$ ). 

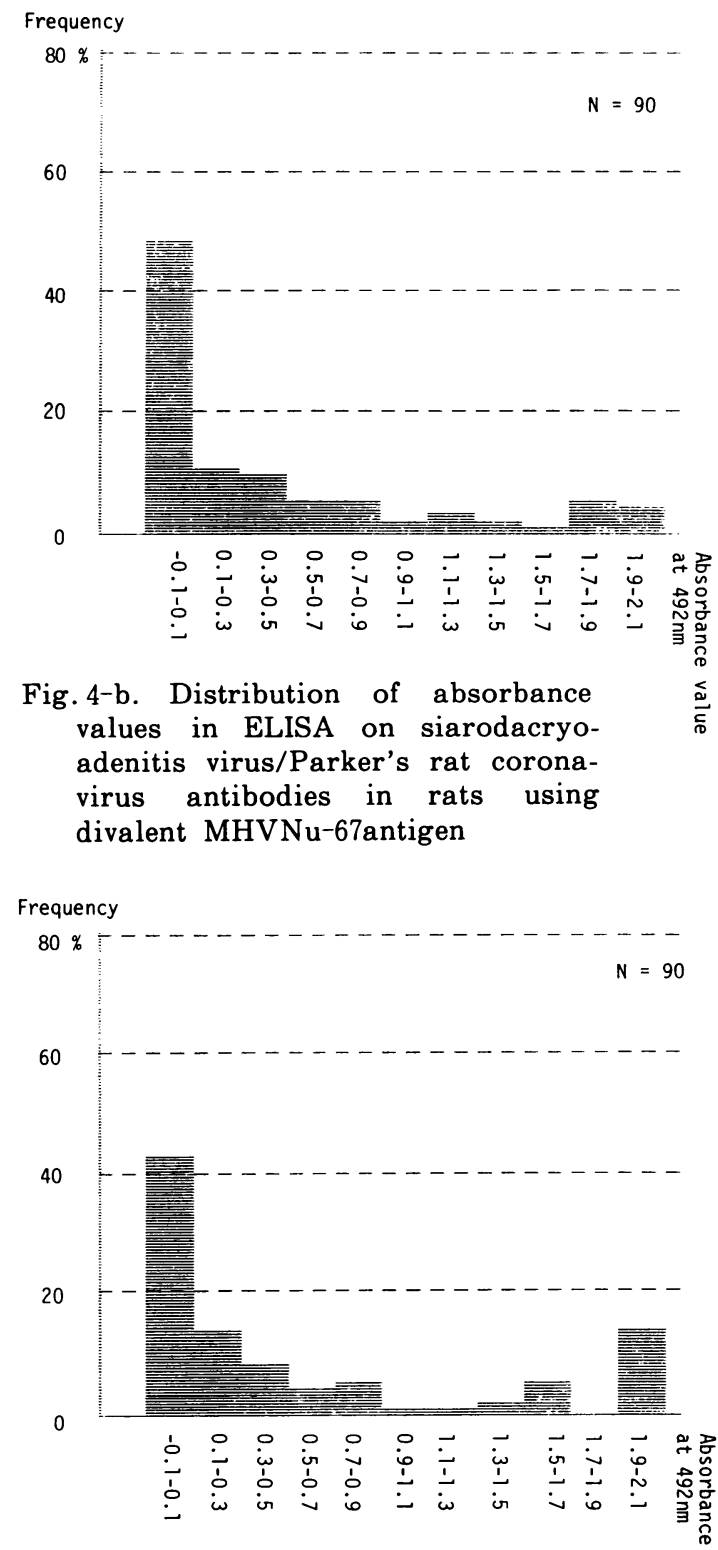

Fig. 4-a. Distribution of absorbance values in ELISA on siarodacryoadenitis virus/Parker's rat coronavirus antibodies in rats using divalent (MHVNu-67+S) antigens

On the other hand, absorbance values shown by 45 samples from contaminated colonies were distributed over a wide range of $0.1-2.1$ ( 9 in the range 0.1 to $0.3,9$ in the range 0.3 to 0.5 , 27 in the range 0.5 to 2.1 ). The absorbance distribution pattern obtained by $\mathrm{Nu}-67$ antigen
(Fig. 4-b) resembled that obtained by divalent antigens (Fig. 4-a). However, differences in absorbance values between non-contaminated and contaminated colonies were not clear, showing -0.1 to 0.5 for the former (39 in the range -0.1 to 0.1 , five in the range 0.1 to 0.3 , one in the range 0.3 to 0.5 ) and -0.1 to 2.1 for the latter (one in the range -0.1 to 0.1 , seven in the range 0.1 to 0.3 , six in the range 0.3 to $0.5,31$ in the range 0.5 to 2.1 ).

\section{Discussion}

The improvement effect of MHV antigen in a prototype ELISA kit was evaluated. The newly prepared divalent antigens showed sufficient reactivity with MHV antibody in mouse sera (Fig. 3-a, b), and an increase in the reliability of macroscopic evaluation of the test was expected. The effect was not so clear for detection of SDAV/PCV antibodies in rat sera (Fig. 4-a, b) although the antigens showed a high reactivity with 21 rat serum samples similar to that of SDAV antigen (Table 2).

Accuracy of the test kit can be evaluated from two standpoints : sensitivity and specificity. The new antigens showed negative reactions (absorbance value : 0.2 or lower) with almost all of the mouse and rat sera obtained from non-contaminated colonies, suggesting the high specificity of the antigen. Evaluation of the sensitivity is not as easy as that of the specificity when it is performed in field investigations because the history of infection of individual animals is usally vague. It was possible that serum samples were collected from animals with insufficient antibody production during the initial period of the infection and also with decreased antibody titers during the convalescent period. From this standpoint, it can not be asserted that the new antigens have inferior sensitivities. In fact, the reactivity of the divalent antigens was as high as that of SDAV antigen with rat sera obtained from a contaminated colony (Table 2).

It has been demonstrated that there are some MHV antigen strains with partially different antigen constructions [1]. Machii et al. [5] investigated reactivties of four murine coronavirus antigens (SDAV, PCV, MHV-S and $\mathrm{MHV}-\mathrm{NuU}$ ) with rat antisera and demonstrated cross-reactivity of MHV-S and MHV- 
$\mathrm{NuU}$ antigens with SDAV and PCV antisera. They suggested the usefulness of MHV antigen for detection of SDAV/PCV infections in rats if highly cross-reactive viral strains are selected. Smith recommended the use of divalent antigens of $\mathrm{S}$ and $\mathrm{JHM}$ for MHV diagnosis using the indirect fluorescence antibody technique [6]. The divalent antigens of $\mathrm{Nu}-67$ and $S$ which we developed for the ELISA kit were also found to have superior accuracy for detection of MHV antibody in mice reared in Japan. Continuous surveillance of $\mathrm{MHV}$ and SDAV/PCV infections in mice and rats using various murine coronavirus antigens is necessary because some changes in the viral strains might occur in these infections.

This study was partially supported by a Grant-in-Aid from the Ministry of Education, Science and Culture, Japan (No. 60880012.)

\section{References}

[1] Fleming, J. O., Stohlman, S. A., Harmon, R. C., Lai, M, M, C., Frelinger, J. A., and Weiner, L. P. (1983). Antigenic relationships of murine coronaviruses :
Analysis using monocional antibodies to JHM (MHV -4) virus. Virology, 131, 296-307.

[2] Hirano, N., Takamaru, H., Ono, K., Murakami, T., and Fujiwara, K. (1986). Replication of sialodacryoadenitis virus of rat in LBC cell culture. Arch Virol, 88, 121-125.

[3] Kagiyama, N., Takakura, A., Koyama, K., Terada, E., and Sakurai, Y. Detection of mouse hepatitis virus antibody by protein A-ELLISA in six prevalent inbred strains or outbred stocks of mice, Lab. Anim, submitted for publication.

[4] Kagiyama, N., Takakura, A., Terada, E., Sakurai, Y., and Suzuki, H. (1989). Studies on the development of an ELISA kit for microbiologicalmonitoring. 1. Evaluation of the reliability of theprototype kit by field tests. Exp. Anim, 39, 87-94.

[5] Machii, K., Iwai, H., Otsuka, Y., Ueda, K., and Hirano, N. (1988). Reactivities of 4 murine coronavirus antigens with immunized or naturally infected ratse ra by enzyme linked immunosorbent assay. Exp. Anim, 37, 251-255.

[6] Smith, A. L. (1983). An immunofluorescence test for detection of serum antibody to rodent coronaviruses. Lab. Anim Sci, 33, 157-160.

[7] Takakura, A., Kagiyama, N., Sakurai, Y., Suzuki, H., Kobayashi, N., and Terada, E. (1988). Detection of Sendai virus antibody in mouse and guinea pig sera by an enzyme-linked immunosorbent assay with protein A. Exp Anim, 37, 279-283.

\title{
微生物モニタリング用 ELISA キットの開発 \\ 2 試作キットの改良一マウス肝炎ウイルス抗原について
}

\author{
鍵山直子・高倉 彰・寺田英司* \\ 櫻井美典**・鉿 木宏和** \\ 財団法人実験動物中央研究所動物医学研究室 \\ *北里大学衛生学部実験動物学研究室 \\ **わかもと製薬株式会社研究部
}

微生物モニタリング用試作 ELISA キットについて， マウス肝炎ウイルス (MHV) 抗原の改良を試みた。そ れぞれ $10 \mu \mathrm{g} / \mathrm{ml}$ の蛋白濃度に調整した MHV Nu-67株 と $\mathrm{S}$ 株の等量混合ダイバレント抗原は, マウスの $\mathrm{MHV}$
抗体およびラットの唾液腺涙腺炎ウイルス／Parker ラ ットコロナウイルス抗体検出にすぐれた感度と特異性を 示した。改良抗原をキットに組み込むことによる，肉眼 判定の信頼性向上が予見された。 